\title{
RESPON ISLAM TERHADAP PERUBAHAN RELASI MASYARAKAT LOKAL DAN NEGARA DI INDONESIA ERA REFORMASI
}

\author{
Muntoha \\ Fakultas Hukum UII \\ email: muntohash@gmail.com, Tamyiz Muharrom, Syari’ah FIAI UII, email: tamyiez@yahoo. \\ co.id, dan Ali Rido, Pascasarjana FH UII, email: ridho.alihasyim@gmail.com
}

Indonesia as a developing country starts moving from the centralistic country into decentralized state since the change of power generated by a wave of reforms in mid 1998. There are several key issues that came to the surface in connection with this transition, among others, is a horizontal conflict that is lead to the disintegration of the Republic of Indonesia (NKRI). In the face of the country situation, the religion (Islam) with the teaching of ethics is expected to be one important factor for the integration process, especially Islam embraced the majority of the Indonesian population. In the study presented formulation of the problem of how the contribution of Islam in the context of the local communities to build relationships and state in Indonesia after the collapse of the New Order regime more equitably? The result of this study has been revealed that the contribution of Islam through the base organization at least can be categorized into three, namely NU, Muhammadiyah, HTI, and MMI. As for the contribution of ideas from NU and Muhammadiyah, that the local community and state relations should be seen in terms of the ideology of Pancasila as the noble nation and agreement of the founders of the nation. Then from HTI, to make the relationship with the local society can be run with a harmonious state is the first system to change the leadership of the country into a caliphate. Furthermore, from the MMI, suggesting if the pattern of the relationship between local communities and the state can run well, then the state must be firm by making Islamic law as its legal basis. It is based on the premise that in Islamic law are values as true and when implemented can provide prosperity for humankind.

Keywords: relasi, Islam, masyarakat lokal, dan kontribusi.

1 Artikel ini merupakan hasil penelitian tim peneliti yang didanai oleh Direktorat Penelitian dan Pengabdian Masyarakat (DPPM) Universitas Islam Indonesia Yogyakarta tahun 2014. Untuk itu, tim peneliti mengucapkan terima kasih kepada pihak DPPM UII yang telah membantu terlaksananya penelitian dimaksud. 


\section{A. Pendahuluan}

Indonesia sebagai negara sedang berkembang mulai bergerak dari negara yang sentralisitik menjadi negara dengan desentralisasi sejak pergantian kekuasaan yang dihasilkan oleh gelombang reformasi di pertengahan tahun 1998. Ada beberapa isu pokok yang mencuat ke permukaan dalam kaitan dengan masa transisi ini antara lain, yaitu pembagian urusan antara pusat dan daerah, pelayanan publik, pembagian sumber pendapatan, lemahnya koordinasi antarsektor, fanatisme daerah, putra daerah, aset daerah dan disintegrasi bangsa. ${ }^{2}$

Sebagian konflik tersebut berkembang ke arah separatisme yang dapat membahayakan integrasi nasional, seperti di Aceh, Papua dan Maluku. Masalah disintegrasi juga muncul di beberapa daerah lain. Hasil jajak pendapat Kompas untuk menyambut Hari Sumpah Pemuda 2002 memperkuat sinyalemen tersebut. Sebagian besar repsonden atau sejumlah $71 \%$ responden menilai bahwa rasa kebangsaan, persatuan, dan komitmen masyarakat untuk mempertahankan keutuhan Negara Kesatuan Republik Indonesia (NKRI) semakin melemah. ${ }^{3}$ Hasil jajak pendapat ini dapat menjadi sinyal yang memperlihatkan fenomena melemahnya ikatan kebangsaan dalam masyarakat Indonesia. ${ }^{4}$

Menghadapi situasi negara seperti tersebut di atas, agama (Islam) dengan ajaran etiknya diharapkan dapat menjadi salah satu faktor penting bagi proses integrasi, apalagi Islam dipeluk mayoritas penduduk Indonesia. Namun, kenyataannya hingga kini Islam belum dapat menjadi perekat yang ampuh bagi integrasi bangsa. Keadaan ini merupakan suatu hal yang ironi dan memprihatinkan karena bangsa Muslim Indonesia sejak masa pergerakan nasional sudah memilih sistem demokrasi sebagai wahana yang terbaik untuk membumikan cita-cita kemerdekaan. ${ }^{5}$ Dari dua kali suksesi kepemimpinan nasional- dari Orde Lama ke Orde Baru - dari Orde Baru ke reformasi diwarnai pertumpahan darah bahkan sekarang ini cenderung anarki dan disintegratif. Padahal, jika dilihat kondisi sosiologis bangsa Indonesia adalah mayoritas muslim dan terkenal berbudaya santun sehingga sangat kontra dengan fakta sejarah politik bangsa Indonesia tersebut.

Kemudian, dengan memperhatikan jalannya reformasi di tanah air sekarang ini dari sudut pandang sosial keagamaan, patut dipertanyakan di manakah sesungguhnya fungsi dan peranan agama-agama, terutama Islam sebagai agama yang dianut mayoritas bangsa Indonesia?. Sebagai motivator, aktor, pendamping, ataukah sebagai "penumpang gelap" reformasi?. Jawaban atas pertanyaan-pertanyaan ini penting diformulasikan karena ia akan menjadi aksioma bagi diskursus keagamaan di Indonesia masa kini dan mendatang dalam kaitannya dengan masalah posisi agama di ruang publik. Dengan sendirinya pula masalah ini secara sosiologis akan terkait dengan pertanyaan masa depan agama-agama, terutama Islam di negeri ini. ${ }^{6}$

2 Mudrajad Kuncoro, Otonomi Daerah dan Pembangunan Daerah : Reformasi, Perencanaan, Strategis dan Peluang, Jakarta: Penerbit Erlangga, 2004, hlm. 38-39.

3 Kompas, Edisi 23 Oktober 2002.

4 Susilo Bambang Yudoyono, "Menata Kembali Kerangka Kehidupan Bernegara Berdasarkan Pancasila", Pidato Presiden Republik Indonesia Dalam Rangka Memperingati Hari Lahir Pancasila, Jakarta Convention Center, 1 Juni 2006.

5 Ahmad Syafi'i Maarif, etc, Satu Islam; Sebuah Dilema, Jakarta: Mizan, 1994, hlm. 160-161.

6 Komaruddin Hidayat, Agama Masa Depan: Perspektif Filsafat Perennial, Jakarta: PT Gramedia Pustaka 
Kemungkinan-kemungkinan yang dapat dikemukakan dalam konteks diskursus di atas, Pertama, jika memang Islam dalam pengertian yang dipahami dan dipraktekkan umat Islam ikut berperan dalam proses reformasi, maka dalam jangka panjang kemungkinan besar Islam masih akan memiliki legitimasi karena memang punya saham untuk ikut memainkan perannya di panggung publik. Kedua, jika anggapan yang muncul bahwa Islam dalam pengertian yang dipahami dan dipraktekkan umat Islam tidak berfungsi apa-apa di dalam proses reformasi, sementara itu anggapan bahwa proses reformasi merupakan babak baru yang sangat penting dalam mengubah haluan sejarah perpolitikan di tanah air, maka dalam jangka panjang Islam akan kehilangan legitimasinya untuk berperan di dalam politik.

Ketiga, jika anggapan keikutsertaan Islam dalam pengertian yang dipahami dan dipraktekkan umat Islam di dalam mengubah haluan sejarah bangsa ini hanya bersifat mozaik dan samar-samar, tidak memberikan sumbangan mendasar, maka hubungan antara Islam di satu pihak dan perubahan politik di pihak lain merupakan hubungan insidental, bukan substansial. Dengan demikian posisi Islam di ranah publik masa-masa yang akan datang masih akan terus dipertanyakan dan diperdebatkan. ${ }^{7}$ Oleh karena itu langkah-langkah pemimpin Islam secara signifikan akan ikut menentukan adakah peran Islam dalam perubahan sosial politik hanya bersifat ad hoc, ataukah memang memiliki kekuatan paradigmatik untuk membangun masa depan bangsa?. Dalam konteks ini para pemimpin Islam dituntut untuk bisa mengambil langkah-langkah strategis dan melibatkan seluruh kekuatan politik yang ada, dalam menuntaskan hubungan agama-negara atau posisi agama di ruang publik.

Persoalan lain, membaca fenomena gerakan Islam di Indonesia dalam konteks membangun masa depan bangsa saat ini mengindikasikan fenomena komunalisme dan primordialisme. Selain itu, realitas ini menunjukkan pula keterpinggiran dan keterasingan yang dihadapi oleh umat Islam dari kekuatan ilmu pengetahuan. Akan tetapi terlepas dari realitas sosiologis ini, fenomena tersebut sebenarnya juga mengandung jebakan. Pertama, jangan-jangan agenda besar bangsa membangun clean government, civil society, dan demokratisasi, tertutup oleh tembok komunalisme di atas. Kedua, fenomena yang menggejala dalam kehidupan bernegara dan berbangsa tengah kehilangan bingkai kebangsaaan karena masing-masing kelompok berada dalam kurungan-kurungan itu. ${ }^{8}$

Fenomena komunalisme dan primordialisme keislaman mengakibatkan Islam telah menjadi instrumen partikularistik gerakan-gerakan agama dan kebangkitan etnis yang kemudian mendapatkan satu legitimasi dari kebijakan politik negara yang berupa otonomisasi dan desentralisasi. Padahal agama pada awalnya menjadi satu perekat pada level civil society. Jika perekat itu hilang dan kemudian diganti oleh ikatan-ikatan komunalisme-parochialisme, ${ }^{9}$ maka konsep dan cita Indonesia akan lenyap perlahan-lahan.

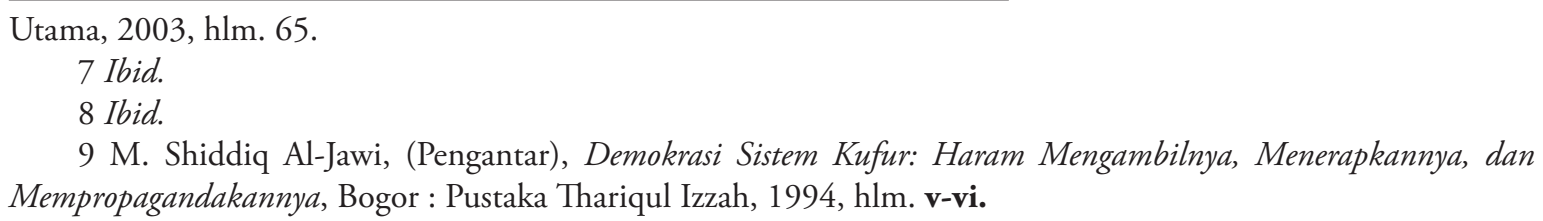


Fenomena bangsa di atas jika dihubungkan dengan kecenderungan politik dan ekonomi global sekarang memunculkan tuntutan dan persyaratan menyangkut demokrasi, pengakuan hak asasi manusia, dan pelestarian lingkungan di satu sisi dan di sisi lain melihat kecenderungan melemahnya ikatan kebangsaan serta menyimak kembali munculnya perlawanan dan penentangan atas NKRI, menempatkan masalah hubungan masyarakat lokal dalam pengertian lingkaran masyarakat adat dan negara pada posisi sentral dalam proses pembangunan di negara-negara berkembang pada abad ke-21. ${ }^{10}$ Persoalan hubungan antara masyarakat adat dan negara telah dan akan menjadi salah satu titik tolak bagi berkembangnya sentimen anti negara dan mendorong munculnya kesadaran politik di tingkat suku bangsa (ethno-nationalism) yang mengancam integrasi negara yang terus meningkat intensitasnya dalam beberapa tahun belakangan ini.

Di masa-masa yang akan datang, jika pesoalan tersebut tidak dapat dicarikan solusinya secara tepat dan cepat, bukan tidak mungkin sentimen anti negara dan ethno-nationalism itu akan makin membesar lagi. Hanya saja jika ini terjadi dalam situasi konsep negara adalah sesuatu yang sakral, disintegrasi itu tentunya akan disertai chaos yang menuntut korban nyawa, rasa perikemanusiaan, dan harta benda. Hal yang demikian inilah yang sama sekali tidak diinginkan. Masalah relasi masyarakat lokal dalam pengertian lingkaran masyarakat adat dan negara di Indonesia menjadi salah satu agenda penting reformasi yang tengah bergulir sejak tumbangnya rezim Orde Baru di pertengahan tahun 1998 yang lalu. Sesuai dengan semangat Pasal 18 Undang-Undang Dasar Negara Republik Indonesia Tahun 1945 (UUD 1945), melalui pemberlakuan UU No. 22 Tahun 1999 yang diubah beberapa kali sampai dengan perubahan dengan UU No. 2 Tahun 2015 dan muncul pula UU No. 6 Tahun 2014 tentang Desa. Akan tetapi apakah penataan ulang relasi masyarakat lokal dan negara tersebut akan memenuhi hakhak dasar masyarakat lokal dan akan menjamin keberlangsungan Negara Kesatuan Republik Indonesia. Oleh karena itu perlu dilakukan studi tentang respons Islam dalam pengertian Islam yang dipahami dan dipraktekkan umat Islam Indonesia terhadap perubahan relasi masyarakat lokal dalam pengertian masyarakat adat dan negara di Indonesia pasca Orde Baru.

Kenyataan di atas dapat dijadikan titik-tolak kemungkinan solusi yang dapat disumbangkan umat Islam terhadap integritas bangsa dewasa ini. ${ }^{11}$ Oleh karena itu, di era reformasi dewasa ini, upaya untuk merealisasikan prinsip-prinsip atau etika politik Islam, seperti persamaan, keadilan atau musyawarah merupakan langkah yang mendesak untuk dilakukan. Sebab, hanya dengan agenda-agenda seperti itulah Indonesia dapat membangun sistem politik modern dan sekaligus menghindari terulangnya krisis baik sosial budaya, ekonomi, maupun politik, seperti yang sedang dialami dewasa ini. ${ }^{12}$ Oleh karena itu, esensi pertanyaan yang penulis kemukakan adalah

10 Mudji Sutrisno dan Hendar Putranto, (eds.), Hermeneutika Pascakolonial, Yogyakarta: Kanisius, 2004, hlm. 20.

11 Abdurrahman Wahid, Islamku Islam Anda Islam Kita: Agama Masyarakat Negara Demokrasi, Jakarta: The Wahid Institute, 2006, hlm. 319.

12 Bahtiar Effendy, Islam dan Negara: Transformasi Gagasan dan Praktik Politik Islam di Indonesia, Jakarta: Democracy Project-Yayasan Abad Demokrasi, 2011, hlm. 154. 
bagaimana kontribusi Islam sebagai suatu landasan dan etika kenegaraan serta sebagai tujuan yang hendak dicapai dalam kehidupan bernegara ditransformasikan dalam konteks membangun relasi masyarakat lokal dan negara di Indonesia pasca runtuhnya pemerintahan Orde Baru secara lebih adil?.

\section{B. Metode Penelitian}

Penelitian ini merupakan penelitian yuridis-empiris dengan menjadikan hasil wawancara sebagai bahan hukum primernya. Guna memperkuat bahan hukum primer, maka digunakan bahan hukum primer dari bagian hukum sekunder berupa peraturan perundang-undangan, buku, hasil penelitian dan sejenisnya yang relevan dengan permasalahan yang dibahas. Dari bahan tersebut digunakan sebagai alat analisisnya.

\section{Pembahasan}

\section{Respon Kontributif Islam Dalam Membangun Relasi Masyarakat Lokal dan Negara Di Indonesia Pasca Runtuhnya Pemerintahan Orde Baru}

a. Respon Kontributif Nahdlatul Ulama (NU)

NU melihat filosofi hubungan masyarakat lokal dan negara di era reformasi (pasca orde baru) dari sudut selalu berkaitan dengan soal bagaimana Islam melihat bentuk negara. Menurut Malik Madani, Katib Syuriyah Pengurus Besar Nahdlatul Ulama (PBNU), Islam adalah agama yang sempurna dan komprehensif dalam keyakinan pemeluknya, termasuk dalam masalah negara. Bahkan ada kaidah yang sering dikutip oleh kalangan NU, dimana negara dilihat sebagai bagian dari sesuatu kewajiban itu tidak sempurna kecuali dengan sesuatu itu maka sesuatu itu hukumnya wajib. Di sini sesuatu itu adalah negara. Al-Ghazali juga menyebutkan bahwa kekuasaan dan agama merupakan dua saudara kembar. Agama merupakan fondasi, dan kekuasaan adalah pengawalnya. Sesuatu yang tidak memiliki dasar, maka dia akan mudah hancur, sedangkan sesuatu yang tidak punya pengawal, maka agama akan tersia-sia. ${ }^{13}$

Sedangkan soal bentuk negaranya, menurut Malik Madani Islam menyerahkannya kepada manusia untuk menetapkan sendiri pilihannya, sesuai dengan tuntutan perkembangan zaman, tempat dan kemaslahatan, karena itu bagian dari urusan dunia. Sistem khilafah, monarki, atau republik hanyalah alternatif yang telah menjadi fakta sejarah. Dalam sabda Nabi Muhammad disebutkan "engkau lebih tahu soal urusan dunia kalian", menjelaskan bahwa Islam menyerahkan urusan dunia termasuk bentuk negara kepada manusia untuk menetapkan sendiri pilihannya, sesuai dengan tuntutan perkembangan zaman, tempat, dan kemaslahatan. Sistem khilafah, monarki, dan republik hanyalah alternatif yang telah menjadi fakta sejarah. Nation-state tidak perlu dipertentangkan dengan Islam, karena al-Qur'an secara eksplisit mengakui eksistensi bangsa dan suku (syu'ub wa qaba'il). Dengan demikian, dapat ditegaskan bahwa adanya state yang didasarkan nasionalitas bukan untuk dipertentangkan. 
Hal terpenting, menurut Malik Madani, kekuasaan negara itu dapat memenuhi unsur: 1). menjaga agama dan mengatur urusan dunia; dan 2). harus ada ketaatan kepada ulu al-amr, yang salah satu maknanya adalah pemerintah, tetapi tidak bersifat mutlak, melainkan harus dalam koridor ketaatan kepada Allah dan Rasul-Nya. Berkaitan dengan ini, Malik Madani melihat bahwa hubungan masyarakat lokal dan negara di Indonesia harus dalam koridor, nilai kearifan lokal dibutuhkan untuk mengisi dan menjadi fondasi bangsa. Pancasila yang terbingkai dalam lima sila, di dalamnya menyerukan nilai-nilai keadaban seperti yang tercantum di dalam sila kedua, sehingga Indonesia tidak boleh ada UU yang melanggar nilai-nilai keadaban yang tumbuh dan berkembang di dalam kehidupan masyarakat lokal.

Sementara menurut Gus Dur, salah satu tokoh panutan NU, hubungan masyarakat lokal dan negara harus didudukkan dalam kerangka Pancasila sebagai ideologi bangsa dan perjanjian luhur para pendiri bangsa. Pancasila memberikan dua konsekuensi: 1. Adanya independensi teologis kebenaran masing-masing masyarakat lokal dan kepercayaan, dan ini diakui; 2. Pancasila perlu bertindak sebagai polisi lalu lintas dalam kehidupan berbangsa, bernegara dan berkepercayaan. Gus Dur menggambarkan ini dengan jelas dalam rumusan sederhana tetapi sangat penting, yaitu: "Semua golongan masyarakat diperlakukan sama oleh undang-undang dan diperlakukan sama oleh negara." ${ }^{14}$ Konsensus itu yang kemudian terumuskan di dalam sila kelima, yaitu Keadilan Sosial Bagi Seluruh Rakyat Indonesia.

Menurut Gus Dur, memang Islam mengundang peranan negara dalam kehidupan kaum muslimin, tetapi Pancasila haruslah didudukan bukanlah menggantikan agama, dan tidak memiliki dimensi keakhiratan. Penjelasan ini satu sisi menimbulkan ketegangan kreatif, karena seakan-akan agama (termasuk Islam) tidak harus patuh kepada Pancasila, tetapi di sisi lain justru Gus Dur melihat perlunya dikembangkan pemikiran untuk mencari nilai-nilai dasar bagi kehidupan bangsa kita. Nilai-nilai dasar itu bisa ditarik dari dua arah: pertama, dari nilai-nilai agama dan kepercayaan, karena ajaran agama akan tetap menjadi referensi umum bagi Pancasila; dan kedua, agama-agama dan kepercayaan harus memperhitungkan eksistensi Pancasila sebagai polisi lalu lintas yang akan menjamin semua pihak bisa menggunakan jalan raya kehidupan bangsa tanpa kecuali. ${ }^{15}$

Berkenaan dengan hal di atas, menurut Gus Dur, nilai-nilai kearifan lokal tetap berperanan dalam negara Pancasila, tetapi harus tetap mempertimbangkan kelapangan dada terhadap aspirasi lain dan Pancasila sebagai polisi lalu lintas yang adil. Kerangka di atas, sebagai bagian dari anak bangsa, maka NU akan selalu memperjuangan Pancasila agar bisa memberikan peluang dan mengadopsi nilai-nilai yang dipeluk umat Islam, terutama faham Aswaja ${ }^{16}$ yang dianut NU. Oleh karena itu, dalam Deklarasi Situbondo yang dibuat para ulama NU disepakati bahwa Pancasila sebagai dasar falsafah negara RI bukanlah agama, tidak dapat menggantikan agama,

14 Abdurrahman Wahid, "Pancasila sebagai Ideologi Kaitannya dengan kehidupan Beragma dan Berkepercayaan terhadap Tuhan Yang Maha Esa”, dalam Oetojo Oesman dan Alfian (Penyunting), Pancasila Sebagai Ideologi, Jakarta: BP7 Pusat, 1991, hlm. 163-168.

15 Ibid.

16 Dalam ajaran Nahdlatul Ulama Aswaja merupakan singkatan dari Ahli Sunnah Wal Jamaah. 
dan tidak dapat digunakan untuk menggantikan kedudukan agama. ${ }^{17}$

Sila kelima menjadi fondasi dalam penyelenggaraan negara dalam memperlakukan warga negaranya. Oleh karena itu, sesuai dengan Pasal 18B UUD NRI 1945 memberikan garansi absolut negara harus menghormati dan mengakui keberadaan keaneragaman masyarakat yang ada di dalam negara tersebut. Dengan begitu, filosofi hubungan agama (khususnya masyarakat local) dan negara pada masa reformasi menurut NU harus berpijak pada dimensi fondasi yang demikian itu, dengan tetap menerima sistem demokrasi sebagai sarana untuk memperjuangkan nilai-nilai yang diiinginan NU, dengan tanpa jalan kekerasan. Pada sisi lain, NU menganggap perjuangan nilai-nilai yang sesuai dengan apa yang diinginkannya akan diperjuangkan sesuai dengan kemampuannya dan segenap tenaga, tanpa harus menganggap orang lain musuh yang harus dilenyapkan.

Pada sisi yang lain, filosofi hubungan masyarakat lokal dan negara pasca reformasi menurut NU telah dikembangkan dalam kerangka HAM. Menurut Nur Khalik Ridwan, ${ }^{18}$ dengan diadopsinya UU HAM dan amandemen konstitusi pada pasal 28, ${ }^{19}$ filosofi hubungan masyarakat dan negara di zaman reformasi sebagian ditempatkan sebagai bagian dari pemikiran tentang HAM, tentu saja dengan pengertian-pengertian yang telah dipilih oleh amandemen dan UU HAM $^{20}$ itu sendiri.

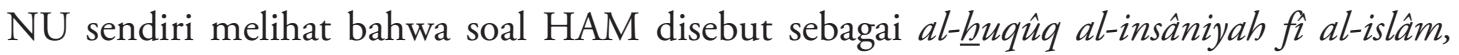
yang melekat pada diri setiap manusia sejak awal dilahirkan yang berlaku seumur hidup dan tidak dapat diganggu gugat oleh siapa pun. Alasan-alasan NU menerima HAM, karena Islam diyakini sebagai ajaran yang menempatkan manusia pada posisi yang sangat tinggi. ${ }^{21}$ Dengan demikian manusia memiliki hak al-karamah dan hak al-fadhîlah, dimana kemashlahatan dan kesejahteraan merupakan tawaran untuk seluruh manusia dan alam semesta.

Elaborasi dari misi kemanusian di atas, maka NU menghargai hak-hak yang disebut sebagai

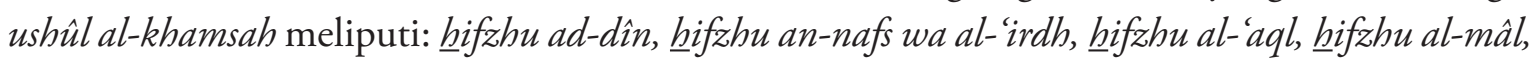
dan hifzhu an-nasl. $\underline{H} i f z h u$ ad-dîn memberikan jaminan kepada umat Islam untuk memelihara agama dan keyakinannya (ad-dîn). Hifzhu an-nafs wa al-irdh memberikan jaminan atas hak setiap jiwa manusia untuk tumbuh dan berkembang secara layak. $\underline{H}$ ifzhu al-'aql memberikan

17 Lebih lanjut, dalam Deklarasi tersebut, bahwa Sila Ketuhanan yang Maha Esa sebagai dasar Negara RI, menurut pasal 29 ayat 1 UUD 45, yang menjiwai sila-sila lain, mencerminkan tauhid menurut pengertian Islam; dan penerimaan dan pengamalan Pancasila merupakan perwujudan dari upaya umat Islam Indonesia untuk menjalankan syari'at Islam. Sebagai konsekuensi sikap di atas, deklarasi ini disudahi dengan kata-kata: "NU berkewajiban mengamankan pengertian yang benar tentang Pancasila yang murni dan konsekuen oleh semua pihak." Lihat "Deklarasi Situbondo tentang Hubungan Pancasila dengan Islam", dalam Abdurrahman Wahid, $N U$ Memasuki Abad Moderen, Gresik: PCNU Cab. Gresik, 1986, hlm. 34.

18 Nur Khalik Ridwan, NU dan Neoliberalisme, Yogyakarta: LKiS, 2008, hlm. 51.

19 Pasal 28 UUD NRI 1945.

20 UU No. 39 tahun 1999 tentang Hak Asasi Manusia.

21 Penerimaan NU atas HAM tersebut, salah satunya didasarkan akan relevansi nash Al Qur'an seperti termaktub di dalam QS al-Isrâ’ ayat 70 yang artinya: Dan sesungguhnya telah Kami muliakan anak-anak Adam, Kami angkut mereka di daratan dan di lautan, Kami beri mereka rezki dari yang baik-baik dan Kami lebihkan mereka dengan kelebihan yang sempurna atas kebanyakan makhluk yang telah Kami ciptakan. 
jaminan atas kebebasan berekspresi, kebebasan mengeluarkan opini, melakukan penelitian, dan berbagai aktivitas ilmiah. Hifzhu an-nasl memberikan jaminan atas kehidupan privasi setiap individu, perlindungan atas profesi, jaminan masa depan, keturunan dan generasi yang lebih berkualitas. Sementara free sex, zina menurut syara', dan homoseksual adalah perbuatan yang dilarang dan bertentangan dengan hifzh an-nasl. Hifzhu al-mâl memberikan jaminan atas kepemilikan harta benda, properti, dan lain-lain, sehingga di dalamnya juga mengakomodir larangan adanya tindakan mengambil hak dari orang lain, seperti mencuri, korupsi, monopoli, oligopoli, monopsoni, dan lain-lain..$^{22}$

Selain itu, filosofi hubungan masyarakat lokal-negara di era reformasi dikerangkakan dengan cara tidak memberikan otonomi daerah dalam soal agama. Dengan demikian, filosofi hubungan masyarakat lokal dan negara di era reformasi, menurut NU tidak boleh terlepas dan tidak bisa dilepaskan dari konstruksi filosofi Pancasila yang menekankan pada aspek dimana individuindividu masyarakat lokal bisa berperanan, tetapi juga harus tetap lapang dada terhadap aspiasi lain.

b. Respon Kontributif Muhammadiyah

Bagi organisasi Muhamadiyah, sebetulnya diskusi tentang relasi masyarakat lokal vis-avis negara, sudah dapat dianggap selesai. Muhammadiyah melihat hubungan keduanya di era reformasi adalah dari sudut pandang Pancasila dan konstitusi, karena menurut Muhammadiyah hubungan keduanya secara filosofis harus didasarkan pada Pancasila dan konstitusi yang di dalamnya nilai-nilai lokalitas harus tetap berperan. Dalam pandangan Muhammadiyah berdasarkan sidang Tanwir di Yogyakarta, menyatakan secara aklamasi bahwa Muhammadiyah mendukung Indonesia sebagai negara Pancasila.

Terkait hal ini, menarik menyimak dua pandangan dari dua tokoh terkemuka di Muhamadiyah, yaitu Amin Rais dan Syafii Maarif. Menurut kedua tohoh ini Indonesia sudah final dengan Pancasila. Syafi'i Maarif menganalogikan bahwa kita lebih baik berpolitik garam dari pada berpolitik gincu. Kalau gincu kelihatan di bibir, tapi rasanya tidak ada, tapi kalau garam tidak kelihatan di air, tapi airnya asin. ${ }^{23}$ Akan tetapi faktanya tentu tidaklah sesederhana analog tersebut. Di internal Muhamadiyah masih terjadi perdebatan sengit terkait hal tersebut. Pandangan tentang Pancasila tidaklah tunggal di internal Muhammadiyah. Tidak sedikit juga dari aktivis ataupun warga Muhammdiyah yang berpandangan bahwa dengan menjadikan Pancasila sebagai asas tunggal, oleh sebagian orang Muhammadiyah diangap tidak sesuai dengan paham Islam yang sesungguhnya. Pancasila dalam kacamata sebagian kelompok Muhammadiyah dianggap tidak kaffah, sehingga masih menyimpan persoalan besar.

Sekalipun AR. Fachruddin telah berupaya menjelaskan dengan sangat apik dengan membuat istilah "wilayah wajib helm" dalam berkendaraan. Seorang yang memakai helm di jalur wajib helm tidak berarti kepala hilang, sekalipun ditutupi, kepala pengendara bermotor tetap ada,

22 Tim PW LTN NU Jawa Timur, Ahkamul Fuqaha, Surabaya: Khalista, 2007, hlm. 666.

23 Zuly Qodir, Tanya Jawab dan presentasi, dalam FGD dengan tema "Hubungan Agama dan Negara dalam Pandangan Ormas Kegamaan” di PSI UII, 29 Januari 2013. 
karena kewajiban memakai helm tidak berarti menghilangkan kepala seseorang. ${ }^{24}$ Terkait analog tersebut, senada dengan Fachruddin, ditegaskan Amien Rais bahwa 'helm' dari analog tersebut adalah Pancasila. Ditambahkan, bahwa Pancasila adalah ibarat karcisnya. ${ }^{25}$

Di internal Muhammadiyah, analog tersebut ternyata tidak serta merta meredam suarasuara yang menyoal Pancasila sebagai asas organisasi. Suara gugatan terhadap Pancasila semakin kuat pasca reformasi. Setelah sekian lama berada dalam tekanan asas tunggal Pancasila di bawah rezim otoriter-birokratik, dalam konteks semacam ini, aktivis-aktivis Muhammadiyah yang menyimpan "dendam" atas dilarangnya penggunaan Islam sebagai asas berorganisasi kemudian bersemangat mengembalikan Islam sebagai asas Muhamadiyah seiring bergulirnya arus reformasi.

Dalam konteks hubungan masyarakat lokal dan ngara, -terlepas dari suara-suara yang menolak Pancasila-, setidaknya mengutip dua pandangan di atas, sudah jelas bahwa hubungan keduanya sangat bersifat subtansial, artinya di dalam masyarakat lokal terdapat nilai yang bersifat subtantif yang mengandung prinsip etis dan moral bermasyarakat dan bernegara. Nilainilai agama harus menjadi acuan dan pedoman dalam menjalankan kehidupan masyarakat dan politik kenegaraan. Karenanya bagi Muhamadiyah, yang terpenting subtansi agamanya dan bukan simbol-simbul lokalitas yang diformalkan.

Bagi Muhammadiyah, masyarakat lokal dan negara tidak ditempatkan dalam konteks dikotomik melainkan ditempatkan dalam posisi yang harmonis dalam bingkai nilai-nilai kemanusiaan dan ketuhanan. Nilai-nilai tersebut sudah terkandung dalam Pancasila, oleh sebabnya menurut Zuly Qodir bisa dipahami jika sejak berdirinya Muhamadiyah, Ahmad Dahlan tidak memikirkan bentuk negara ke depan, tapi fokus menafsirkan tiga hal dari surat al-Ma'un. Yaitu (1) membuat masyarakat cerdas, yaitu membuat institusi pendidikan, (2) menyantuni orang miskin, dan (3) membuat orang Islam sehat. ${ }^{26}$

Sedangkan dalam soal bentuk negara, argumentasi Muhamadiyah relatif senada dengan pandangan NU, bahwa Islam menyerahkannya kepada manusia untuk menetapkan sendiri pilihannya, sesuai dengan tuntutan perkembangan zaman, tempat dan kemaslahatan, karena itu bagian dari urusan dunia. Sistem khilafah, monarki, atau republik hanyalah alternatif yang telah menjadi fakta sejarah. Dalam sabda Nabi Muhammad disebutkan "engkau lebih tahu soal urusan dunia kalian", menjelaskan bahwa Islam menyerahkan urusan dunia termasuk bentuk negara kepada manusia untuk menetapkan sendiri pilihannya, sesuai dengan tuntutan perkembangan zaman, tempat, dan kemaslahatan. Nation-state tidak perlu dipertentangkan dengan Islam, karena al-Qur'an secara eksplisit mengakui eksistensi bangsa dan suku (syu'ub wa qaba'il). Adanya state yang didasarkan nasionalitas bukan untuk dipertentangkan. ${ }^{27}$

Doktrin Islam tidak pernah menetapkan suatu rezim pemerintahan tertentu, tidak pula

24 Zully Qodir, Muhammadiyah, Islam dan Nasionalisme, dalam buku Moh. Sofan, Satu Abad Muhamadiyah; Mengkaji Ulang Arah Pembaruan, Jakarta; Paramadina, 2010, hlm. 74

25 Zuly Qodir, Tanya Jawab.., 29 Januari 2013.

26 Zuly Qodir, Tanya jawab..., 29 Januari 2013.

27 Ibid 
mewajibkan kepada kaum Muslimin agar menganut suatu sistem pemerintahan tertentu untuk memerintah. Islam telah memberikan kita kebebasan mutlak untuk mengorganisasikan negara sesuai dengan kondisi-kondisi intelektual, sosial, dan ekonomi yang kita miliki, dan dengan mempertimbangkan perkembangan sosial dan tuntutan zaman. Karenananya, masalah bentuk maupun sistem negara akan dijalankan dan diserahkan pada umat sesuai dengan perkembangan sosial dan zaman, termasuk dibebaskan untuk memilih Pancasila dan sistem demokrasi jika sistem dan nilai-nilai yang ada tersebut sudah dianggap sesuai dan bertentangan dengan agama (Islam).

Deskripsi di atas, menunjukan bahwa relasi masyarakt lokal dan negara menurut Muhamadiyah sesungguhnya sudah sangat jelas dan tegas, yaitu menerima Pancasila karena nilai-nilai yang terkandung di dalamnya tidak bertentangan dengan ajaran agama (Islam). Hal itu juga tercermin sebagaimana tertuang dalam Matan Keyakinan dan Cita-Cita Hidup Muhamadiyah $(\mathrm{MKCH})$ yaitu pada rumusan ke-5 yaitu bahwa Muhamadiyah mengajak semua lapisan bangsa Indonesia yang telah mendapat karunia Allah berupa tanah air yang mempunyai sumber-sumber kekayaan, kemerdekaan bangsa dan negara Republik Indonesai yang berdasarkan Pancasila dan UUD NRI 1945, untuk berusaha bersama-sama menjadikan suatu negara yang adil dan makmur yang diridhai Allah SWT; baldatun tayyibatun warobbul ghofuri. ${ }^{28}$ Rumusan kelima ini memuat persoalan mengenai fungsi dan misi Muhamadiyah dalam masyarakat (bangsa) dalam bingkai NKRI.

Konsekuensi dari itu, Muhamdiyah harus berpijak pada dimensi fondasi Pancasila dengan tetap menerima sistem demokrasi sebagai sarana memperjungkan nilai-nilai yang diinginkan Muhamadiyah dengan tanpa jalan kekerasan. Seperti pernyataan Amien Rais di muka, bahwa demokrasi memang pilihan yang paling bagus buat manusia modern, sekalipun demokrasi memang tidak sempurna, namun barangkali merupakan sistem politik yang paling mendekati ajaran-ajaran agama. ${ }^{29}$

Dalam kerangka demikian, seperti halnya NU, Muhamadiyah sebagai bagian dari anak bangsa, berkomitmen memperjuangkan Pancasila agar bisa memberikan peluang dan mengadopsi nilai-nilai yang dipeluk umat Islam, terutama nilai kemanusiaan, keadilan, kehidupan harmonis, kemakmuran, pendidikan dan supermasi hukum yang kesemuanya sesungguhnya sudah terkandung dalam Pancasila. Oleh sebabnya, Pancasila wajib diamankan dari berbagai upaya kelompok-kelompok garis keras yang berkehendak mengganti ideologi pancasila. Kalau nilainilai universal Islam tersebut di atas, sudah terjiwai dalam Pancasila mengapa harus mengganti dengan ideologi (negara) Islam. Komitmen Muhamadiyah dalam mempertahankan Pancasila sebagai falsafah dan dasar negara di era reformasi ini dapat dilihat misalnya dalam kasus infiltarsi ideologi garis keras yang berorientasi pada pendirian negara Islam di tubuh Muhamadiyah. ${ }^{30}$

28 Djamaludin Ahmad Al-Buny, Pendidikan Kemuhamadiyahan, Surabaya; PT. Bina Ilmu, 1990, hlm.77

29 Amien Rais, Keraifan Dalam Ketegasan: Renungan Indonesia Baru, (Yogyakarta: Bigraf Publishing, 1999), hlm. 107-108

30 Respon tegas Muhamadiyah berkenaan dengan dikeluarkannya Surat Keputusan Pimpinan Pusat (SKPP) Muhamdiyah No. 149/Kep /1.0/B/2006. SKPP ini dikeluarkan bertujuan untuk menyelamatkan Muhamadiyah dari berbagai tindakan yang merugikan persyarikatan. Terdapat 10 butir keputusan yang dituangkan dalam SKP, 
Dengan demikian, filosofi hubungan masyarakat lokal dan negara di era reformasi menurut Muhammadiyah sangat bersifat subtansial, artinya dalam masyarakat lokal terdapat ajaran dan nilai yang bersifat subtantif yang mengandung prinsip etis dan moral bermasyarakat dan bernegara yang bisa dijadikan dasar bernegara. Hubungan keduanya tidak ditempatkan dalam konteks dikotomik melainkan dalam posisi yang harmonis dalam bingkai nilai-nilai kemanusiaan dan ketuhanan.

Namun demikian, nilai-nilai lokalitas harus menjadi acuan dan pedoman dalam menjalankan kehidupan masyarakat dan politik kenegaraan. Selain itu yang terpenting subtansi agamanya dan bukan simbol-simbul kegamaan yang diformalkan. Namun demikian, harus diakui memang selalu terdapat kelompok yang berpandangan berbeda menyikapi hubungan negara dan masyarakat lokal dalam internal Muhamadiyah. Hal tersebut bisa dipahami, karena selama priode negara otoriter-birokratik di era rezim orde baru, aktivitas Muhamadiayah berada dalam naungan asas tunggal Pancasila, yang oleh sebagian orang Muhamadiyah bahkan hingga kini masih dianggap tidak sesuai dengan paham yang sesungguhnya.

Oleh sebagian orang Muhammadiyah, Pancasila dianggap tidak kaffah sehinga masih menyimpan persoalan yang relatif serius di tubuh Muhamadiyah. Gerakan tersebut semakin lebih terasa dan massif seiring diperolehnya kebebasan berpendapat dan berekpresi di era reformasi. Namun sebagaimana dikemukakan Zuly Qodir bahwa jumlah mereka yang mengaspirasikan atau menolak Pancasila sebagai dasar negara di internal Muhamadiyah tidaklah signifikan jumlahnya, justru arus besarnya malah menerima Pancasila sebagai dasar dan falsafah negara Indonesia.

c. Respon Kontributif Hizbut Tahrir Indonesia (HTI)

Pandangan HTI tentang filosofi hubungan masyarakat lokal dan Negara di era reformasi, jika dikaji tidaklah ada pandangan khusus. Pandangan mereka masih simpang siur, ada pergeseran, dan saling bertentangan. Dalam seluruh gagasan HTI, bentuk negara yang diidealkan adalah negara khilafah sebagai negara Islam, dan ini berimpalikasi pada bentuk dasar filosofi tentang bangsa, sehingga hal ini berkaitan dengan filosofi Pancasila.

Dalam buku Negara Khilafah, disebutkan jenis negara Islam, yaitu: "Sistem pemerintahan Islam yang diwajibkan oleh Tuhan alam semesta adalah sistem khilafah." ${ }^{11}$ Dalam buku Daulah Islam disebutkan: "Pemerintahan dalam daulah Islam ada empat, yaitu pengangkatan seorang khalifah, kekuasaan adalah milik umat, kedaulatan berada di tangan syara', dan hanya khalifah yang berwewenang untuk mentabanni (maksudnya mungkin membuat) hukum-hukum syara', dengan kata lain menjadikannya sebagai perundang-undangan. Jika salah satu dari kaidahkaidah ini hilang, maka pemerintahannya menjadi tidak Islami, bahkan harus menyempurnakan

namun secara garis besar tindakan yang merugikan tersebut antara lain adalah infilterasi di tubuh Muhamadiyah dari organisasi lain yang memiliki paham, misi dan kepentingan yang berbeda dengan Muhamadiyah. Terutama pada paham yang berorientasi pada pendirian Negara Islam yang jelas bertentangan Muhamadiyah yang secara tegas menerima Pancasila sebagai dasar Negara. Abdurahman Wahid (editor), Ilusi Negara Islam: Ekspansi Gerakan Islam Transnasional di Indonesia, Jakarta; The Wahid Institut, 2009, hlm. 179-182.

31 Hizbut Tahrir, Struktur Negara Khilafah, Jakarta: HTI Press, 2006, hlm. 14. 
seluruh kaidah yang empat itu seluruhnya." ${ }^{32}$

Dengan konsep itu, yang disebut negara Islam adalah "khalifah yang menerapkan sistem Islam. Khilafah (kekhalifahan) atau imâmah (kepemimpinan) adalah pengaturan tingkah laku secara umum atas kaum Muslim, artinya khilafah bukan bagian dari akidah, tetapi bagian dari hukum syara. ${ }^{33}$ Secara detil gagasan negara Islam tergambar dalam Rancangan Undang-undang Dasar (RUUD) yang dilampirkan dalam buku Daulah Islam. Selain yang disebut negara Islam, disebut oleh HT sebagai darul kuffar, yang didefinisikan sebagai: "Tempat yang di dalamnya diterapkan hukum-hukum kufur, dan atau keamanannya tidak berdasarkan Islam, yaitu tidak berada di tangan kekuasaan dan pertahanan kaum muslimin, meskipun penduduknya mayoritas orang Islam. ${ }^{34}$

Gagasan HTI di atas, menegaskan bahwa negara dengan filosofi dan dasar Pancasila bukanlah negara Islam. Oleh karena bukan negara Islam, maka tidak termasuk dikategorikan sebagai Darul Kuffar. Untuk menegakkan negara khilafah, menurut HTI harus dilakuan:

1) Berjuang bersama-sama menghadapi negara-negara kafir imperialis yang menguasai atau mendominasi negara-negara Islam, berjuang menghadapi segala bentuk penjajahan, baik berupa pemikiran atau ide-ide, politik ekonomi, maupun militer, mengungkap strategi yang mereka rancang, membongkar persekongkolan mereka untuk menyelamatkan umat dari kekuasaan dan membebaskannya dari seluruh pengaruh dominasi mereka;

2) Menentang para penguasa di negara-negara Arab maupun negara-negara Islam lainnya, mengungkapkan kejahatan mereka, menyampaikan nasihat, dan kritik kepada mereka, dan berusaha untuk meluruskan mereka, setiap kali mereka merampas hak-hak rakyat atau pada saat mereka melalaikan kewajibannya kepada umat, atau bila mereka menyimpang dari hukum-hukum Islam. Di samping itu, HTI juga membangun opini bahwa sistem demokrasi merupakan sistem kufur yang tidak layak dijadikan acuan dalam bernegara. ${ }^{35}$

Dari sudut gagasan ini, sudah jelas HTI bertentangn dengan negara Pancasila yang bukan negara khilafah. Akan tetapi dalam tubuh Hizbut Tahrir (HT) di Indonesia yang bernama HTI, terjadi pergeseran, sebagaimana ditunjukkan pada tahun 2005 ketika HTI mengubah dirinya dari partai politik dengan agenda HT, menjadi Ormas HTI dengan segala konsekuensinya. Perubahan HTI menjadi Ormas ini, dapat dilihat berdasarkan surat Depdagri Dirjen Kesatuan Bangsa dan Politik, No. 44/D.III.2/VI/2006. tentang terdaftarnya HTI sebagai Ormas di Depdagri. Surat tersebut menyebutkan:

"Memperhatikan UU No. 8 tahun 1985 tentang Ormas; PP No. 18 tahun 1986; Permendagri No. 5 tahun 1986; dan surat permohonan No. 125/DPP-HTI/X/2005 tanggal 13 Oktober 2005 setelah diadakan penelitian kelengkapan organisasi, dengan ini Dirjen Kesatuan Bangsa dan Politik Depdagri menyatakan: Hizbu Tahrir Indonesia, periode kepengurusan 2005-2007, dengan alamat Gedung Anakida Lt. 4 Ruang 403,

32 Taqiyuddin an-Nabhani, Daulah Islam, dalam Ihsan Samarah, Syaikh Taqiyuddin an-Nabhani Meneropong Perjalanan Spiritual dan Dakwahnya, Bogor: Al-Azar Press, 2003, hlm. 300.

33 Ibid., hlm. 301.

34 Ibid.

35 Ibid., hlm. 52. 
Jl. Prof Soepomo No. 27, Tebet Jaksel, telp. 021 8353254, telah terdaftar sebagai organisasi kemasyarakat, dan dalam melaksanakan kegiatannya agar tidak bertentangan dengan ketentuan perundang-undangan yang berlaku..." ${ }^{36}$

Tidak hanya didaftarkan sebagai Ormas yang mengakui Pancasila, juru bicara HTI, Ismail Yusanto menyebutkan bahwa secara filosofis spirit syariat Islam terkandung di dalam Pancasila, tetapi HTI memahami Pancasila hanya sebatas seperangkat gagasan filosofis. Pancasila dengan sila-silanya tidak ada yang buruk dan tak salah. Tetapi, Pancasila tak mencukupi untuk mengatur masyarakat Indonesia. Oleh karena itu tidak heran, meski semua rezim mengakui Pancasila, tapi sistem yang dipakai bermacam-macam. Di masa Soekarno, Pancasila ditafsirkan sebagai sistem sosialistik, di masa kepemimpinan Soeharto, Pancasila diterapkan dalam sistem kapitalistik. Namun di masa sekarang ada kecenderungan membawa Pancasila pada sistem neoliberal. Dengan demikian, dapat diartikan bahwa letak masalah bukan di Pancasila, tetapi dari sistem di bawahnya. Karena sifatnya hanya gagasan filosofis, maka Pancasila kemudian digunakan untuk melancarkan paham yang dianut penguasa." 37

Kesimpangsiuran ini, ditambahkan oleh Yoyok, Humas HTI DIY, yang menyebutkan:

"Saya mewakili pengurus HTI, tapi hanya saja, setelah saya konfirmasi, tidak ada pendapat HTI. Berbeda dengan Muhammadiyah dan NU yang mengatakan "ini final”. Apa yang disampaikan di sini, lebih banyak pendapat saya. Jadi sejak pada tahun 1980 tidak ada pendapat resmi tentang Pancasila." ${ }^{38}$

Kesaimpangsiuran ini, juga semakin jelas ketika muncul sebuah tulisan dari O. Solihin yang memperkenalkan diri sebagai orang yang pernah di HTI. Menurutnya adanya surat legalitas HTI menjadi Ormas dan mengakui Pancasila itu bermasalah. Persyaratan menjadi Ormas harus mengakui perundang-undangan yang berlaku di Indonesia. Padahal, hukum di Indonesia menurutnya adalah hukum kufur, bukan Islam. Ia pun berkomentar:

"Bagaimana mungkin kita mengemis-ngemis dan meminta legalitas dari sistem yang kita sebut kufur. Ini menurut saya bukan uslûb (cara), tapi sudah tharîqah (metoda). Maka, menyalahi tharîqah tentu kesalahan yang sangat mendasar. Malah, sebenarnya uslûb pun harus sesuai dengan tharîqah. Tidak boleh menyimpang dari tharîqah. "39

Bukan hanya itu saja, O. Solihin menunjukkan bahwa perubahan HTI yang berbeda dengan HT di Timur Tengah dan menjadi Ormas ini disebutnya mereduksi nilai-nilai dari definisi partai politik itu sendiri. Sehingga terjadi yang namanya contradictio in terminis yaitu partai politik, tapi Ormas. Hal ini sungguh bukan saja kontradiksi istilah, tapi sekaligus menghancurkan bangunan yang selama ini ditetapkan oleh pendiri Hizbut Tahrir, bahwa Hizbut Tahrir adalah partai politik. Sehingga, jika menjadi Ormas, tentu saja adalah kemunduran dan mengaburkan

36 Lihat selengkapnya dalam Surat Depdagri Dirjen Kesatuan Bangsa dan Politik, No. 44/D.III.2/VI/2006.

37 Presentasi Ismail Yusanto dalam diskusi dan bedah buku "Pancasila 1 Juni dan Syariat Islam" di Megawati Institute, Rabu, 11 Agustus tahun 2011.

38 Yoyok Tindyo Prasetyo, Presentasi dan Tanya Jawab, di PSI UII, 29 Januari 2013.

39 O Solihin, "HTI dari Parpol Berubah Menjadi Ormas", dalam www.osolihin.wordpress.com, diakses 23 Mei 2015. 
makna perjuangan dan bahkan sangat boleh jadi "telah mengkhianati pendirinya. ${ }^{40}$

Pemaparan di atas, semakin jelas bahwa telah terjadi pergeseran dan pergolakan dalam HT dan HTI. Secara eksplisit mereka tidak memiliki pandangan tentang Pancasila sebagai dasar negara dan filosofi bangsa dan banyak menghindar ketika ditanya soal itu, tetapi karena mereka telah menjadi ormas maka suka atau tidak suka harus mengakui Pancasila yang dinilai bertentangan dengan gagasan para pendiri dan pemimpin HT sendiri. Bahkan, dengan adanya argument bahwa spirit syariat Islam terkandung di dalam Pancasila, maka berarti masalahnya ada dalam pelaksanaan dan penjabarannya, bukan sebagai dasar negara.

Apabila diamati dari gagasan-gagasan dan tulisan HTI, jelas bahwa tanpa mengaitkan dengan filosofi Pancasila, mereka mengritik perjalanan reformasi, dari sudut perlawananya terhadap demokrasi, kapitalisme, korupsi, eksploitasi alam, kemiskinan, dan lain-lainnya. Solusinya, selalu dihubungan dengan penerapan syariat Islam dan khilafah, tetapi pada saat yang sama mereka tidak mau mengaitkan dengan Pancasila, apalagi membahasnya dari sudut sebagai dasar negara yang dibutuhkan bangsa Indonesia.

d. Respon Kontributif Majelis Mujahdin Indonesia (MMI)

Hhubungan masyarakat lokal dan negara pasca reformasi, menurut MMI harus berpijak pada konsep dakwah, baik dakwah secara politik maupun sosial. Dalam kedua konsep dakwah tersebut, adalah mengajak manusia untuk mengesakan Allah SWT, dan menerapkan syariahNya, sebagai satu-satunya way of life (manhajul hayah), ketetapan dan ketentuan serta aturan hidup manusia. Manusia dilarang menyandingkan tatanan lain di samping syari'at Allah SWT sebagai tatanan kehidupan di dalam urusan apapun. Sedangkan jihad yang dimaksudkan di sini adalah, usaha sungguh-sungguh untuk memperjuangkan dan menerapkan syariah Islam dalam semua segi kehidupan, baik secara pribadi, keluarga, masyarakat, berbangsa dan bernegara; termasuk perlawanan (usaha pembelaan diri) ketika diserang. ${ }^{41}$

MMI memiliki pandangan bahwa dalam Islam terdapat ajaran yang menyeluruh (totalitas) mulai dari penyucian diri (individu) sampai pada mengatur masyarakat dan negara (politik) totalitas iniilah yang diyakini oleh ketua MMI Irfan S Awwas. Ia berpandangan Islam mengatur seluruh kehidupan masyarakat baik sosial, ekonomi dan politik. Inilah yang kemudian menjadi sumber konsepsi bersatunya masyarakat dan negara. ${ }^{42}$

Gerakan Islam yang memperjuangkan syariat Islam di Indonesia era reformasi dilakukan melalui dua pola, yakni pola kekuasaan dan pola kultural. Dalam memperjuangkan syariat Islam, pertama, gerakan ini melakukan lobi-lobi kekuasaan (DPR, MPR dan partai politik) dan melakukan berbagai upaya persuasif untuk menguasai masyarakat. Dalam prakteknya, biasanya mereka menguasai masyarakat terlebih dahulu baru kemudian mengislamkan kekuasaan. Melalui pola kekuasaan, Front Pembela Islam, HTI, dan MMI, menggelar aksi dukungan kepada partaipartai politik yang memperjuangkan syariat Islam. Bahkan, MMI sudah membuat amandemen

$40 \mathrm{Ibid}$.

41 Irfan S. Awwas, Dakwah dan Jihad Abu Bakar Baasyir, Yogyakarta: Wihdah Press, 2003, hlm. 31.

42 Khamani Zada, Islam Radikal: Pergulatan Ormas-Ormas Islam Garis Keras di Indonesia, Jakarta: Teraju, 2002, hlm. 102. 
UUD 1945 yang sesuai dengan syariat Islam.

Sementara strategi kedua, atau yang disebut pola kultural, yakni memberikan dakwah Islam kepada masyarakat agar proses islamisasi secara menyeluruh berjalan lancar. Bagi MMI, masyarakat adalah sasaran dakwah Islam yang paling efektif dan bukan negara. Mereka menyadari, kalau masyarakat sudah memberlakukan syariat Islam, maka secara otomatis negara akan mengikuti aspirasi masyarakat. ${ }^{43}$

Secara umum, agenda dan tujuan utama gerakan Islam Syariat adalah menyerukan agar syariat diimplementasikan secara kaffah (total) oleh negara. Karena, menurut mereka, relasi masyarakat dan negara bersifat integralistik. Inilah doktrin yang selalu mereka tanamkan, yaitu Islam adalah agama sekaligus kekuasaan. Dengan demikian, pemberlakuan syariat Islam merupakan sebuah kewajiban dan meninggalkannya berarti murtad (keluar dari Islam). Berkenaan dengan pandangan MMI terhadap Pancasila sebagai dasar negara, MMI melalui juru bicaranya Irfan S Awwas, justru mengajukan pertanyaan "benarkah Pancasila itu dasar negara RI?", mengingat di dalamnya juga ada sila Ketuhanan Yang maha Esa; dan pertanyaan apa definisi negara Pancasila?. Secara lengkap pertanyaan tersebut dapat dilihat sebagai berikut:

"Kalau kita sepakat Ketuhanan Yang Maha Esa itu adalah konsep agama, maka seharusnya negara Pancasila yang berdasarkan Ketuhanan Yang Maha Esa. Menurut Prof Hazairin, SH seorang mufasir Pancasila mengatakan "di negara Pancasila yang berdasarkan Ketuhanan Yang Maha Esa adalah negara yang membuat undang-undang tidak boleh bertentangan dengan ajaran agama”. Persoalannya pendapat Hazairin ini tidak menjadi pendapat pemerintah Indonesia. Jadi menurut MMI, kalau setuju bahwa Ketuhanan Yang Maha Esa sebagai dasar, maka hubungan agama pasca reformasi, semua ketentuan perundangan tidak boleh bertentangan dengan ajaran agama.., Kita ini membangun Indonesia berlandaskan pada sekulerisme atau agama. kalau berlandaskan pada Ketuhanan YME, itu berlandaskan konsep agama.”44

Visi MMI sendiri sejak awal berdirinya sudah sangat jelas yaitu tegaknya negara Islam. Namun berbeda dengan HTI, meskipun MMI menggugat Pancasila sebagai dasar Negara ${ }^{45}$, Organisasi pimpinan Abu Ja'far Baasyir tersebut tidak mengharuskan nama khilafah dan tidak mempersoalkan bentuk dan nama. Hal yang penting adalah pengawalan negara bagi penegakan Syariat Islam ${ }^{46}$ dan dapat mempersatukan umat Islam. Sejalan dengan pandangannya ini, MMI

43 Lihat Khamami Zada, "Wacana Syariat Islam: Menangkap Potret Gerakan Islam Di Indonesia”, dalam Tashwirul Afkar, Edisi No. 12. Tahun 2012, hlm, 32.

44 Ibid

45 Irfan S Awwas, dalam wawancaranya dengan jurnalis muslim yang tergabung dalam JITU (Jurnalis Islam Bersatu) menyatakan (tahun 2000) bahwa temuan MMI terkait Pancasila pancasila sebagai dasar Negara. Menurutnya Pancasila itu ternyata bukan dasar negara selama ini, kita tertipu termasuk nyanyian Garuda Pancasila. Karena itu MMI akan meminta penjelasan kepada MK, dan DPR. Dalam http;//ustadz-dunia.b http://ustadzdunia.blogspot.com/2013, diakses 23 Mei 2015.

46 Sekadar catatan gerakan untuk menerapkan Syariat Islam di sejumlah daerah merupakan fenomena yang menonjol di era reformasi. Gerakan ini hampir bersamaan dengan perjuangan mengusung Piagam Jakarta tahun 2000 yang dilakukan oleh kelompok-kelompok umat Islam dalam organisasi keagamaan termasuk MMI 
menolak demokrasi dan tidak setuju dengan nasionalisme karena merupakan produk Barat. ${ }^{47}$ Sikap ini mempertunjukkan secara jelas bahwa MMI juga menolak NKRI karena Negara ini secara terang benderang menganut sistem yang ditolak. ${ }^{48}$

Dari sudut gagasan, sudah jelas MMI bertentangan dengan negara Pancasila yang bukan negara khilafah. Negara Pancasila menganut sistem demokrasi dan menjadikan NKRI sebagai putusan final. Dengan pemahaman ini, sangat ekplisit MMI anti terhadap ide-ide kebangsaan yang telah terkandung dalam nilai-nilai Pancasila, demokrasi dan semangat NKRI. Karenanya sikap penolakan MMI dan termasuk juga HTI tersebut sering dianggap bersifat setengah hati. Dikatakan demikian karena kendati mereka pada hakikatnya menolak dalam realitasnya tetap mengambil hak-hak yang senyatanya menjadi hak warga Negara Indonesia. Padahal dengan penolakan tersebut mereka seharusnya tidak berhak lagi mengklaim sebagai warga negara Indonesia. Seiring itu, hak-hak yang dimiliki warga negara dengan sendirinya menjadi hilang dari mereka. ${ }^{49}$

Negara Islam dalam pandangan MMI wajib ditegakkan karena memiliki peran sebagai institusi perantara untuk penegakan syariat Islam. Jadi, negara Islam menjadi satu prasyarat utama yang harus dipenuhi bagi tegaknya Syariat Islam. Negara Islam menjadi satu kekuatan struktural sehingga sejumlah hukum Islam, seperti qisas dan rajam bisa secara efektif dilaksanakan di masyarakat. Lebih jauh, MMI berargumen bahwa penegakan syariat merupakan bagian integral dari penegakan agama (iqâmah al-dîn) secara keseluruhan. ${ }^{50}$ Pelaksanaannya harus dilakukan secara komprehensif (kâffah), hal ini didasarkan atas tiga alasan: ${ }^{51}$

1) Islam adalah agama yang mengatur dunia dan akhirat (dîn wa l-dawlah).

2) Sejarah umat Islam memperlihatkan pemerintahan Islam sejak Nabi Muhammad, masa

di dalamnya. Gerakan formalisasi syariat Islam ini berlangsung relatif luas di berbagai daerah,, seperti Sulawesi Selatan, Jawa Barat dan sebaginya. Selengkapnya lihat Haedar Nashir, Islam Syariat: Reproduksi Salafiyah Ideologis di Indonesia, Jakarta: Penerbit Mizan, 2013, hlm. 282.

47 Resistensi terhadap apa yang berbau Barat tampaknya sudah menjadi karaketristik MMI dan bahkan organisasi fundamnetalis lainnya seperti HTI, FPI dan orrganisasi fundamentalis lainnya. Bentuk paling keras dari resistensi mereka terhadap hegemoni Barat, tampaknya dari tindakan melakukan jihad yang dengan tegas mengatasnamakan Islam dalam merusak simbol-simbol kekafiran, menghujat dengan cara-cara yang tidak manusiawi. Cara-cara seperti ini selalu merupakan bagian dari sebuah strategi politik, yakni penggunaan kekerasan secara terus menerus, dan bersifat ragasia oleh kelompok tertentu untuk tujuan-tujuan politik dan memiliki pengaruh langsung terhadap kebijakan publik dan berupaya menyesuaikan dogma Islamis demi kepentingan kehormatan politis dan dukungan rakyat. Kehormatan politis di sini bisa dimaknai sebagai upaya atau strategi politik untuk menarik simpati rakyat dengan menggunakan bendera agama yang menjadi kepedulian sentral untuk melindungi kelompoknya dari dominasi kekuatan militer, ekonomi ataupun gagasan-gagasan yang bercorak asing (Barat). Selengkapnya baca Budy Munawwar Rahman, "Memahami Gerakan Islam Syariat", Makalah pada acara bedah buku" Islam Syariat: Reproduksi Salafiyah Ideologis di Indonesia”, Balai Penelitian dan Pengembangan Agama, Jakarta 27 Pebruari 2014.

48 Abd. A'la, "Sikap Muslim Fundamentalis Terhadap NKRI Antara Penolakan dan Penerimaan Setengah Hati”, dalam Jurnal UNISIA, (Vol. XXXIII No, 73, Juli 2010). hlm. 7.

49 Abd a'la, Sikap Muslim...,hlm. 7

50 Budhy Munawwar Rahman, "Memahami Gerakan.....Loc. Cit, hlm. 3.

51 Habib Rizieq Shihab, "Jika Syariat Islam Jalan, Maka Jadi Negara Islam”, Tashwirul Afkar, Edisi No. 12 Tahun 2002, hlm. 98-100. 
keempat khalifah, hingga Dinasti Usmaniyyah menjunjung tinggi penegakan syariat Islam secara menyeluruh.

3) Pengaruh globalisasi yang menawarkan pemikiran dan budaya sekular telah mengancam keberadaan dan kesucian sejarah Islam di kalangan umat Islam sendiri. Maka, menurut MMI kembali kepada supremasi syariat menjadi kewajiban yang harus dipenuhi oleh seluruh umat Islam.

Apabila dicermati dari gagasan-gagasan dan tulisan MMI terkait hubungan masyarakat dan negara di era reformasi di atas, jelas bahwa tanpa mengaitkan dengan filosofi Pancasila, mereka mengkritik perjalanan reformasi, dari sudut perlawananya terhadap demokrasi, kapitalisme, korupsi, eksploitasi alam, kemiskinan, dan lain-lainnya. Solusi yang ditawarkan mereka, selalu dikaitkan dengan penerapan syariat Islam dan khilafah, tetapi pada saat yang sama mereka tidak mau mengaitkan dengan sudut pandang Pancasila, apalagi membahasnya dari sudut sebagai dasar negara yang dibutuhkan bangsa Indonesia.

\section{Penutup}

Kontribusi Islam melalui basis organisasinya setidaknya dapat dipetakan menjadi tiga, yaitu NU, Muhammadiyah, HTI, dan MMI. Adapun dari NU, kontribusi yang diberikan, bahwa hubungan masyarakat lokal dan negara harus didudukkan dalam kerangka Pancasila sebagai ideologi bangsa dan perjanjian luhur para pendiri bangsa. Pancasila memberikan dua konsekuensi: adanya independensi teologis kebenaran masing-masing masyarakat lokal dan kepercayaan, dan ini diakui; dan Pancasila perlu bertindak sebagai polisi lalu lintas dalam kehidupan berbangsa, bernegara dan berkepercayaan. Hal yang tidak jauh berbeda juga diuraikan oleh Muhammadiyah, mereka menyarankan bahwa hubungan negara dan masyarakat lokal harus diletakan pada konsepsi Pancasila dan konstitusi. Di samping itu, nilai-nilai lokalitas harus tetap berperan dalam menjalankan roda kebijakan negara.

Kemudian, dari HTI tidak ada pandangan khusus tentang filosofi hubungan masyarakat lokal dan Negara di era reformasi dalam kenegaraan RI. Bagi HTI, untuk menjadikan hubungan masyarakt lokal dengan negara dapat berjalan dengan harmonis adalah dengan merubah terlebih dahulu sistem kepemimpinan negara menjadi khalifah. Selanjutnya, dari MMI melihat bahwa hubungan masyarakat lokal dan negara pasca reformasi, berpijak pada konsep dakwah, baik dakwah secara politik maupun sosial. Artinya, MMI menyarankan jika pola hubungan antara masyarakat lokal dengan negara dapat berjalan dengan baik, maka negara harus tegas dengan menjadikan syariat Islam sebagai dasar hukumnya. Hal ini didasarkan pada alasan bahwa di dalam syariat Islam terdapat nilai-nilai yang kaffah dan bilamana diimplementasikan dapat memebrikan kesejahteraan bagi umat manusia. 
$28 \mid$ Muntoha

\section{Bibliografi}

\section{Buku}

Al-Buny, Djamaludin Ahmad, 1990, Pendidikan Kemuhamadiyahan, Surabaya; PT. Bina Ilmu. an-Nabhani, Taqiyuddin, 2003, Daulah Islam ,dalam Ihsan Samarah, Syaikh Taqiyuddin anNabhani Meneropong Perjalanan Spiritual dan Dakwahnya, Bogor: Al-Azar Press.

Al-Jawi, M. Shiddiq, 1994, Demokrasi Sistem Kufur: Haram Mengambilnya, Menerapkannya, dan Mempropagandakannya, Bogor : Pustaka Thariqul Izzah.

Awwas, Irfan S., 2003, Dakwah dan Jihad Abu Bakar Baasyir, Yogyakarta: Wihdah Press.

Effendy, Bahtiar, 2011, Islam dan Negara: Transformasi Gagasan dan Praktik Politik Islam di Indonesia, Jakarta: Democracy Project-Yayasan Abad Demokrasi.

Hidayat, Komaruddin, 2003, Agama Masa Depan: Perspektif Filsafat Perennial, Jakrta: PT Gramedia Pustaka Utama,

Hizbut Tahrir, 2006, Struktur Negara Khilafah, Jakarta: HTI Press.

Kuncoro, Mudrajad, 2004, Otonomi Daerah dan Pembangunan Daerah : Reformasi, Perencanaan, Strategis dan Peluang, Jakarta: Penerbit Erlangga.

Maarif, Ahmad Syafi'i, dkk, 1994, Satu Islam; Sebuah Dilema, Jakarta: Mizan.

Haedar Nashir, 2013, Islam Syariat: Reproduksi Salafiyah Ideologis di Indonesia, Jakarta: Penerbit Mizan.

Oesman, Oetojo dan Alfian (Penyunting), 1991, Pancasila Sebagai Ideologi, Jakarta: BP7 Pusat.

Rais, Amien, 1999, Keraifan Dalam Ketegasan: Renungan Indonesia Baru, Yogyakarta: Bigraf Publishing.

Ridwan, Nur Khalik, 2008, NU dan Neoliberalisme, Yogyakarta: LKiS.

Sofan, Moh., 2010, Satu Abad Muhamadiyah; Mengkaji Ulang Arah Pembaruan, Jakarta; Paramadina

Sutrisno, Mudji dan Hendar Putranto, 2004, Hermeneutika Pascakolonial, Yogyakarta: Kanisius.

Tim PW LTN NU Jawa Timur, 2007, Ahkamul Fuqaha, Surabaya: Khalista.

Wahid, Abdurrahman, 1986, NU Memasuki Abad Moderen (Gresik: PCNU Cab. Gresik. 2006, Islamku Islam Anda Islam Kita: Agama Masyarakat Negara Demokrasi, Jakarta: The Wahid Institute. , (editor), 2009, Ilusi Negara Islam: Ekspansi Gerakan Islam Transnasional 
di Indonesia, Jakarta; The Wahid Institut.

Zada, Khamani, 2002, Islam Radikal: Pergulatan Ormas-Ormas Islam Garis Keras di Indonesia, Jakarta: Teraju.

\section{Hasil Penelitian, Makalah dan Jurnal}

A'la, Abd., 2010, Sikap Muslim Fundamentalis Terhadap NKRI Antara Penolakan dan Penerimaan Setengah Hati, Jurnal UNISIA, Vol. XXXIII No, 73, Juli.

Rahman, Budhy Munawwar, 2014, Memahami Gerakan Islam Syariat, Makalah pada acara bedah buku” Islam Syariat: Reproduksi Salafiyah Ideologis di Indonesia”, Balai Penelitian dan Pengembangan Agama, Jakarta 27 Pebruari.

Yudoyono, Susilo Bambang, 2006, Menata Kembali Kerangka Kehidupan Bernegara Berdasarkan Pancasila, Pidato Presiden Republik Indonesia Dalam Rangka Memperingati Hari Lahir Pancasila, Jakarta Convention Center, 1 Juni.

\section{Media}

Kompas, Edisi 23 Oktober 2002.

O Solihin, HTI dari Parpol Berubah Menjadi Ormas, dalam www.osolihin.wordpress.com, diakses 23 Mei 2015.

Shihab, Habib Rizieq, Jika Syariat Islam Jalan, Maka Jadi Negara Islam, Tashwirul Afkar, Edisi No. 12 Tahun 2002.

Zada, Khamami, Wacana Syariat Islam: Menangkap Potret Gerakan Islam Di Indonesia, Tashwirul Afkar, Edisi No. 12. Tahun 2012

\section{Wawancara}

Madani, Malik, Tanya Jawab dan Presentasi, dalam FGD dengan tema Hubungan Agama dan Negara dalam Pandangan Ormas Kegamaan” di PSI UII, 29 Januari 2013.

Prasetyo, Yoyok Tindyo, Tanya Jawab dan Presentasi, dalam FGD dengan tema Hubungan Agama dan Negara dalam Pandangan Ormas Kegamaan” di PSI UII, 29 Januari 2013.

Qodir, Zuly, Tanya Jawab danPresentasi, dalam FGD dengan tema Hubungan Agama dan Negara dalam Pandangan Ormas Kegamaan” di PSI UII, 29 Januari 2013.

Presentasi Ismail Yusanto dalam diskusi dan bedah buku "Pancasila 1 Juni dan Syariat Islam" di Megawati Institute, Rabu, 11 Agustus tahun 2011. 


\section{Peraturan Perundang-undangan}

Undang-Undang Dasar Negara Republik Indonesia Tahun 1945.

Republik Indonesia. Undang-undang Nomor 39 Tahun 1999 tentang Hak Asasi Manusia.

Surat Depdagri Dirjen Kesatuan Bangsa dan Politik, No. 44/D.III.2/VI/2006. 